\title{
How do First Year Students Form Their Project Teams?
}

\author{
Elizabeth Maggs, Carol Hulls, Chris Rennick, and Mary Robinson \\ University of Waterloo \\ emmags@edu.uwaterloo.ca, chulls@uwaterloo.ca, crennick@uwaterloo.ca, mary.robinson@uwaterloo.ca
}

\begin{abstract}
Common wisdom of how students, form their teams for projects is "who they know", not necessarily who would make a good teammate, nor someone they can actually work with.

In their first semester on campus, Mechatronics students have multiple opportunities to work with their classmates, any of which could have contributed to how they formed their course project team. The activities range in scope from straightforward assignments to challenging projects, and vary in length from one, to several weeks.

This research was conducted as a sequential explanatory, mixed-methods study. First semester team formation data was cross-checked with survey responses, and student self-reporting on satisfaction with their choice of team members. Focus groups were then conducted to investigate external forces on team formation.

Conclusions from the initial work show that students are much more strategic with who they work with than initially hypothesized and the motivations behind the choice of teammates are diverse, and complex. Further work needs to be completed to see how widespread these motivations are across Engineering at UWaterloo.
\end{abstract}

Keywords: First year, team formation, team performance

\section{INTRODUCTION}

There are two main ways to form student teams: either the instructor assigns students to a team or the students create the teams by themselves. Student selected teams have the ability to excel; typically, a student chosen team will experience less friction because the students are already familiar with one another and therefore are better at cooperating [1]. Furthermore, students working with their friends in a group generally don't want to let their friends down and so they are willing to work harder [1]. Studies show that students prefer to choose their own group [2]. Consequently, when students are working in a group they chose themselves, they are more likely to work harder. Another major benefit to having students select their own teams is that there will be less complaining about how the teams were formed [1]. If groups are chosen by the professor or are randomly selected, and any problems are experienced within these groups, students may blame the problems their group is experiencing on the fact that they did not choose their own groups. However, if students form their own groups then they cannot blame any group issues on how the group they are working with was chosen, because they chose it themselves.

There are also many drawbacks to allowing students to form their own teams. Generally, when students form their own groups they tend to gravitate toward working with people within their social network of friends or students sitting within close proximity. This method of selecting group members does not take into account the knowledge, skills and abilities each member will contribute [2]. Furthermore, students of comparable abilities tend to congregate together; this means strong students gravitate towards strong students and weak towards weak. Ultimately, groups that form like this was will hinder both the weak and strong groups. Weaker students will not be exposed to how stronger students approach problems and stronger students do not have the opportunity to experience peer teaching the weaker students [3]. As a counter example however, in our experience with groups completing open-ended projects, uniform skill levels can work well by allowing a group of strong students to produce an extraordinary result, and forcing a group of weak students to engage with the material because there is no one to take over and "rescue" the project.

Working with a group of friends does not necessarily mirror what teams in the workplace are like: typically, teams of coworkers are not friends [1]. A group of friends does not always possess the required skills to excel at the project. However, since students are not typically given any direction on effective ways of selecting suitable team members, by default they choose to work with their friends [2]. Finally, Oakley et.al. observe that in their experience incidences of cheating are higher for self-selected groups [4].

The Mechatronics students investigated in this paper were presented with several opportunities to work with people they would not necessarily choose to work with early in the term, before choosing their own team for the multi-week, course project. Therefore, it is of interest to determine whether these students ended up forming final project groups based off friendships they have with their classmates, or through some other means. 


\section{CONTEXT AND METHODOLOGY}

This study is related to a larger body of work being undertaken by members of the Engineering Ideas Clinic (EIC) Teamwork Committee at the University of Waterloo [5]. The focus of this paper is to examine how first semester (1A) Mechatronics students form their student teams when given the freedom to choose their own teammates. In the first semester of the Mechatronics (MTE) program at UWaterloo, there are many opportunities to work in pairs and in larger teams across the five courses they take. In the most recent semester (fall 2016), students worked in:

- instructor-assigned pairs on 7, week-long programming assignments in GENE 121 (Digital Computation, a course in $\mathrm{C}++$ )

- assigned teams of three on the fuel cell car assignment for CHE 102 (Chemistry for Engineers) and MTE 100 (Mechatronics Engineering) [6]

- assigned teams of 4 to dissect a snowblower engine in MTE 100 (one 3-hr lab)

- self-selected teams for Tron Days (2-day long design event) [7]

- self-selected teams for their final integrated course project for GENE 121/ MTE 100 (5 week long project) [8]

This study was originally conceived as a quantitative study to investigate what effect team-based term activities had on final project group formation in the 1A term. The initial data collection and analysis was completed in December 2016. Our original hypothesis was that collaborative coursework partnerships would have a large effect on team formation for the final project. This turned out not to be the case, and so further investigation was required. The study was then extended to a sequential explanatory mixed methods study. The quantitative data examined included cross-referencing team make-up in the programming assignments, fuel cell car groups, and for 2016, the students' Tron Days teams, with the final project groups. Survey data was also collected two ways: at the end of the fall semester in a survey that has been delivered in the first semester of the MTE program since 2013; and from an anonymous survey, with targeted questions related to team formation which was given out after lectures in the winter 2017 semester to all MTE streams who were on campus. The qualitative data collected was from a series of three focus groups that were run with students from the first, second, and third year classes who are on campus in the winter 2017 semester.

The GENE 121/MTE 100 course project is the highlight of the first semester of the MTE program for both the students and the teaching team. This project has been running in a similar format since 2012, and is an important step in students forming an identity as a Mechatronics
Engineer. The work they conduct to complete this project is often the only Engineering experience they have on their resume, and as half of the students go out for their first work term after just one semester, it is critical that the experience be a good one. To that end, the 1A MTE teaching team have been incorporating the teamwork training modules developed by the EIC Teamwork Committee since that initiative started in 2015.

The results of this study will be useful to other course instructors when debating whether to let students choose their own teams vs. assigning teams themselves. There are additional internal uses of the results of this study: to validate that the effort spent on team activities in the $1 \mathrm{~A}$ semester is effort well spent, as well as to uncover what specific team makeup leads to success so proper advice can be given to students when they form their own teams.

\section{RESULTS \& DISCUSSION}

The results of this research are presented in chronological order of when the associated analysis was completed.

\subsection{Fall 2016 Quantitative Data Results and Discussion}

In fall 2016, an undergraduate co-op student conducted the first stage of this research by cross-referencing the lists of student teams from the 1A MTE semester. This included the instructor-assigned GENE 121 programming partners for all weeks before the project starts, the instructor-assigned student teams for the fuel cell car project, and for 2016, the self-selected student teams for Tron Days (which ran for the first time in 2016). Table 1 below, summarizes the results from cross-referencing GENE 121 partners against the final project teams.

Table 1 Number of final project groups with former GENE121 partners

\begin{tabular}{|l|l|l|l|l|l|l|l|}
\hline & \multicolumn{6}{|l|}{ GENE 121 Assignment } & Total \\
\hline & $\mathbf{2}$ & $\mathbf{3}$ & $\mathbf{4}$ & $\mathbf{5}$ & $\mathbf{6}$ & $\mathbf{7}$ & $\mathbf{\#}$ \\
\hline${ }^{'} \mathbf{1 4}$ & 8 & 3 & 7 & 3 & 3 & NA & 16 \\
& $15 \%$ & $6 \%$ & $13 \%$ & $6 \%$ & $6 \%$ & & $30 \%$ \\
\hline${ }^{'} \mathbf{1 5}$ & 3 & 2 & 7 & 3 & 2 & 2 & 16 \\
& $6 \%$ & $4 \%$ & $13 \%$ & $6 \%$ & $4 \%$ & $4 \%$ & $31 \%$ \\
\hline${ }^{'} \mathbf{1 6}$ & 6 & 1 & 6 & 1 & NA & NA & 14 \\
& $11 \%$ & $2 \%$ & $11 \%$ & $2 \%$ & & & $25 \%$ \\
\hline
\end{tabular}

There are a noticeable number of final project teams with at least some members from former programming partnerships. There are also interesting increases in the number of final project teams with programming partners from Assignment 2 and Assignment 4. Assignment 2 is the first assignment which is completed in pairs (the first assignment is individual), and so this could be the first time 
students have worked with a University classmate on anything. Assignment 4 is typically the first assignment that the students struggle to complete. This assignment also introduced RobotC and the Lego Mindstorms platform (which they will use for the course project) in 2015 and 2016, which leads to larger collaboration in that week's programming assignment. For assignments with RobotC, the students are always excited to play with the hardware, and as they don't have access to the equipment at home, the RobotC portion of the assignment must be completed in the lab session when both partners are present working together on the same hardware. The weeks labelled as NA indicate weeks after the project teams have been formed.

The Fuel Cell Car teams are normally formed in the second week of the semester, with the first written deliverable due around week 3 of the term. In 2015, students signed out the fuel cell car itself in week 4 . The Fuel Cell Car project was run differently in 2016 due to the addition of Tron Days, so students never signed out a car for themselves, they just borrowed one during the lab sessions when they were needed. Table 2 summarizes the number of final project groups with former members from a fuel cell car team. The fuel cell car teams were groups of four in 2015, and groups of three in 2016. As with the GENE 121 programming partners, some teams are forming with former fuel cell project teammates, but the large majority are not forming this way. The Fuel Cell Car project is a difficult, frustrating project for students, and so it's possible that they do not want to work with those people again because of this.

Table 2 Number of final project groups with former fuel cell car partners

\begin{tabular}{|l|l|l|l|}
\hline & $\begin{array}{l}\text { 3 same } \\
\text { members }\end{array}$ & $\begin{array}{l}\text { 2 same } \\
\text { members }\end{array}$ & $\begin{array}{l}\text { No same } \\
\text { members }\end{array}$ \\
\hline $\mathbf{2 0 1 5}$ & $1(2 \%)$ & $13(25 \%)$ & $38(73 \%)$ \\
\hline $\mathbf{2 0 1 6}$ & 0 & $6(11 \%)$ & $49(89 \%)$ \\
\hline
\end{tabular}

Tron Days [7] ran for the first time in early October, 2016. All traditional classes, tutorials and labs were rescheduled for a two-day period to allow students to fully engage with large, ambiguous, engineering design problems. The students selected their own teams of 4 for this event. Table 3 below, summarizes the number of final project groups with common Tron Days teammates.

Table 3 Number of 2016 final project groups with common Tron Days partners

\begin{tabular}{|l|l|}
\hline $\begin{array}{l}\text { \# members } \\
\text { in common }\end{array}$ & \# Groups \\
\hline 4 & $18(33 \%)$ \\
\hline 3 & $8(15 \%)$ \\
\hline 2 & $20(36 \%)$ \\
\hline 0 & $9(16 \%)$ \\
\hline
\end{tabular}

Clearly Tron Days had a large impact on final project team formation. This begs the question, how did they identify and select their Tron Days teammates? Table 4 and Table 5 below summarize the cross-referencing of Tron Days team members with GENE 121 programming partners and fuel cell car teams. Very few Tron Days teams formed from either of these activities, and the data we had available could not explain how these teams formed.

Table 4 Number of Tron Days groups with former GENE 121 partners

\begin{tabular}{|l|l|}
\hline Assign. \# & \# Teams \\
\hline 2 & $5(10 \%)$ \\
\hline 3 & $0(0 \%)$ \\
\hline 4 & $3(6 \%)$ \\
\hline
\end{tabular}

Table 5 Number of Tron Days groups with former fuel cell car partners

\begin{tabular}{|l|l|l|}
\hline $\begin{array}{l}\text { 3 same } \\
\text { members }\end{array}$ & $\begin{array}{l}\text { 2 same } \\
\text { members }\end{array}$ & $\begin{array}{l}\text { No same } \\
\text { members }\end{array}$ \\
\hline 0 & $5(10 \%)$ & $47(90 \%)$ \\
\hline
\end{tabular}

The Mechatronics program is typically between 15 and $20 \%$ female, representing a total female population of between 30 and 40 students. Students may be forming teams along gender lines, especially as women are underrepresented in the program. Table 6 summarizes team composition by the percentage of team members who were identified by the researchers as female. As the students were not given an opportunity to self-identify their gender when these numbers were tallied, there could be an error of \pm 1 student. The data shows that there are some teams formed along gender lines ( 5 teams out of 52 in 2015, and 6 teams out of 55 in 2016 are majority female), however there are far more teams that don't appear to have formed due to the gender of the teammates.

Table 6 Final project groups, gender makeup

\begin{tabular}{|c|c|c|c|c|c|}
\hline & \multicolumn{5}{|c|}{ \# teams (total \# female students in category) } \\
\hline & $\begin{array}{l}25 \% \\
\text { female }\end{array}$ & $\begin{array}{l}33 \% \\
\text { female }\end{array}$ & $\begin{array}{l}50 \% \\
\text { female }\end{array}$ & $\begin{array}{l}75 \% \\
\text { female }\end{array}$ & $\begin{array}{l}100 \% \\
\text { female }\end{array}$ \\
\hline 2015 & $8(8)$ & $1(1)$ & $5(10)$ & $4(12)$ & $1(4)$ \\
\hline 2016 & $13(13)$ & $1(1)$ & $2(4)$ & $3(9)$ & $3(8)$ \\
\hline
\end{tabular}

There remains a large percentage of final project teams who appear to have formed from students who had never worked together during the semester. Why did they choose these people? How did they know them, and how well did they know them? How successful were these teams? None of these questions could be readily answered with the available data, and so the investigation was expanded. 


\subsection{Winter 2017 Quantitative Data Results and Discussion}

The anonymous team formation surveys, given to four classes of students in the winter 2017 semester, served two purposes. The first was to investigate how, and if, students knew each other before classes started in their first semester on campus. The second purpose was to poll the students on how they knew the students they worked with on the final project.

Table 7 below, summarizes how students knew their classmates before their $1 \mathrm{~A}$ classes started. The class size for the $1 \mathrm{~B}, 2 \mathrm{~A}$ and $3 \mathrm{~A}$ classes are approximately 100 students, the 3B class has approximately 120 . The numbers of survey responses by class are presented at the bottom of

Table 7.

Orientation week stands out as the single most important event for students to meet their future classmates. This data also shows a larger percentage had attended a previous school with their University classmates than was expected. Table 8 and Table 9 below summarize how students knew their Tron Days partners, and their final project partners. As this data is from the same survey, response rates are identical to those reported in

Table 7.

Table 7 Number of students who knew classmates from before University

\begin{tabular}{|l|l|l|l|l|}
\hline & $\mathbf{1 B}$ & $\mathbf{2 A}$ & $\mathbf{3 A}$ & $\mathbf{3 B}$ \\
\hline Orientation week & 45 & 19 & 14 & 35 \\
\hline Previous school & 31 & 12 & 16 & 21 \\
\hline Residence & 12 & 12 & 11 & 19 \\
\hline Pre-Univ projects & 7 & 2 & 3 & 2 \\
\hline Facebook & 2 & 0 & 0 & 2 \\
\hline Univ. club/team & 1 & 0 & 0 & 0 \\
\hline Eng 101 & 1 & 1 & 0 & 0 \\
\hline Open House & 0 & 0 & 0 & 1 \\
\hline Friends & 0 & 0 & 0 & 1 \\
\hline Job & 0 & 1 & 0 & 0 \\
\hline Didn't know any & 16 & 17 & 8 & 14 \\
\hline \# Responses & $\mathbf{7 3}$ & $\mathbf{4 8}$ & $\mathbf{3 4}$ & $\mathbf{6 8}$ \\
\hline
\end{tabular}

Table 8 How students knew Tron Days teammates, 2016 only

\begin{tabular}{|l|l|}
\hline & 1B \\
\hline Orientation week & 21 \\
\hline Previous school & 14 \\
\hline Residence & 7 \\
\hline Facebook & 5 \\
\hline Friends & 5 \\
\hline Pre-univ projects & 2 \\
\hline Eng 101 & 1 \\
\hline Univ. club/team & 0 \\
\hline Didn't know any & 10 \\
\hline
\end{tabular}

Table 9 How students knew final project teammates

\begin{tabular}{|l|l|l|l|l|}
\hline & 1B & 2A & 3A & 3B \\
\hline Classwork & 26 & 16 & 15 & 25 \\
\hline Tron Days & 16 & NA & NA & NA \\
\hline Residence & 10 & 24 & 7 & 22 \\
\hline Orientation week & 10 & 10 & 5 & 19 \\
\hline Previous school & 7 & 4 & 8 & 5 \\
\hline Friends & 4 & 9 & 0 & 3 \\
\hline Pre-Univ projects & 2 & 1 & 2 & 0 \\
\hline Facebook & 1 & 1 & 0 & 3 \\
\hline Univ. club/team & 0 & 0 & 0 & 1 \\
\hline Eng 101 & 1 & 2 & 0 & 1 \\
\hline Random assign. & 0 & 0 & 0 & 4 \\
\hline Didn't know any & 2 & 0 & 0 & 0 \\
\hline
\end{tabular}

The importance of Orientation Week for providing opportunities to meet future classmates was startling. That students formed teams based on friendships, and living arrangements (roommates) is less surprising, and confirms previous research into team formation. It is also encouraging that classwork represents a large percentage of how students found their teammates. As these surveys were anonymous, it is impossible to cross-reference individual student responses on the team formation survey with the other quantitative data gathered.

\subsection{Student Satisfaction with Teammates}

Identifying a measure that indicates whether a student project was "successful" or not is difficult. Team grades on the project were considered as an option, however a good project with a poorly written final report will show up as a low grade (as communication is the focus of the project deliverables in MTE 100). Counting the number of students who mention their final project on their resume could also potentially be a measure of a successful project (at least in the eyes of the student), however as many 1A MTE students have no other engineering experience to speak of, most, if not all of them, include the project on their resume. Student satisfaction in their project teammates was ultimately the most effective measure of success.

In the end of term survey given to the MTE students after their $1 \mathrm{~A}$ semester, they are asked to what level they agree with the following prompt: "All group members contributed equally to the project". This survey is not anonymous to the researchers, though it is anonymous to course instructors, so student responses to this prompt could be cross-referenced with how their teams formed (Note: this study has received formal ethics clearance from UWaterloo's Office of Research Ethics). Table 10 summarizes the team formation data for any teams where at least one team member strongly agreed that all members contributed equally to the final course project. Table 11 
summarizes the team formation data for any teams where at least one team member strongly disagreed that all members contributed equally.

Table 10 Summary of Strongly Agree responses to "All group members contributed equally to the final project"

\begin{tabular}{|l|l|l|}
\hline & $\mathbf{2 0 1 5}$ & $\mathbf{2 0 1 6}$ \\
\hline Total \# groups with Strongly Agree & 16 & 30 \\
& $(31 \%)$ & $(55 \%)$ \\
\hline \# groups with GENE121 partners + & 5 & 11 \\
Strongly Agree & $(10 \%)$ & $(20 \%)$ \\
\hline \# groups with fuel cell partners + & 2 & 5 \\
Strongly Agree & $(4 \%)$ & $(9 \%)$ \\
\hline \# groups with Tron Days partners + & NA & 26 \\
Strongly Agree & & $(47 \%)$ \\
\hline
\end{tabular}

Table 11 Summary of Strongly Disagree responses to "All group members contributed equally to the final project"

\begin{tabular}{|c|c|c|}
\hline & 2015 & 2016 \\
\hline $\begin{array}{lrll}\text { Total \# } & \text { groups } & \text { with } & \text { Strongly } \\
\text { Disagree } & & & \\
\end{array}$ & $\begin{array}{l}6 \\
(12 \%)\end{array}$ & $\begin{array}{l}12 \\
(22 \%)\end{array}$ \\
\hline $\begin{array}{l}\text { \# groups with GENE121 partners + } \\
\text { Strongly Disagree }\end{array}$ & $\begin{array}{l}1 \\
(2 \%)\end{array}$ & $\begin{array}{l}2 \\
(4 \%)\end{array}$ \\
\hline $\begin{array}{l}\text { \# groups with fuel cell partners + } \\
\text { Strongly Disagree }\end{array}$ & 0 & $\begin{array}{l}1 \\
(2 \%)\end{array}$ \\
\hline $\begin{array}{l}\text { \# groups with Tron Days partners + } \\
\text { Strongly Disagree }\end{array}$ & NA & $\begin{array}{l}7 \\
(13 \%)\end{array}$ \\
\hline
\end{tabular}

Teams which formed from students who had previously worked together on term assignments had a higher reported satisfaction with the contributions of their teammates than teams which formed in other ways. In 2016, teams with members who had worked together during Tron Days showed a very high satisfaction with their final project teammates. This is a highly promising result of Tron Days that will hopefully continue in future terms. Figure 1 below shows a summary of the class-wide aggregated responses to "All group members contributed equally". There was little change in the total percentage of people who either agreed or strongly agreed from 2015 to 2016 , however there is a sharp rise in the percentage of people who strongly agreed.

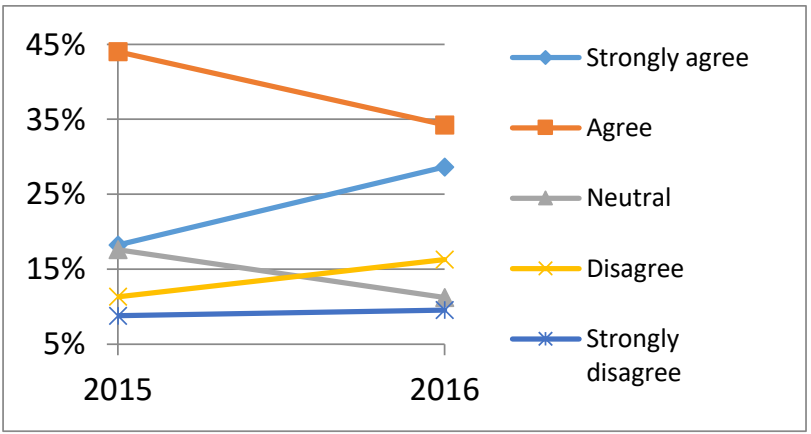

Figure 1 Summary of responses to "All group members contributed equally"
It is interesting to note that in 2016 , there were two teams where at least one member strongly agreed, and at least one member strongly disagreed that all group members contributed equally. In 2015, there was one group which fell into this category. These teams were investigated further. For the 4-person group in 2015, one member strongly agreed, and two members strongly disagreed. The 2015 team had a large imbalance in student performance in the programming course among team members (one student in the 50 's, three in the 80 's in GENE 121). Of the two teams in 2016, one was formed by the teaching team of leftover students, and so issues could be expected. The second team, however, cannot be easily explained. The team by all accounts had a successful project (project grades in both MTE 100 and GENE 121 were very strong), and was balanced as far as programming ability (one member in the 70s, 3 in the 80s in GENE 121). Why one student would strongly disagree and two would strongly agree cannot be explained without interviewing the students involved.

\subsection{Focus Group Results}

Three focus groups were conducted in the winter 2017 semester. The focus group participants were recruited through an open email that went out to the entire cohort. No effort was made to recruit any one subset of people over another. The class of 2021, who were in their second semester of first year (1B) had six participants show up (4 female, 2 male). The class of 2020, in their first semester of second year (2A) had six participants show up (3 male, 3 female). The class of 2019, in their first semester of third year (3A) had five participants show up (3 male, 2 female). In all three focus groups, females were over-represented compared to the gender makeup of the cohorts. One confounding factor that was not investigated further is that the classes of 2020 and 2021 have received the first two Ideas Clinic Teamwork workshops, while the class of 2019 has not (and will not).

The focus group response was too small and not representative of the class as a whole so we cannot make general conclusions. Nonetheless, the comments provided did give a richer picture as to how teams formed within the Mechatronics class cohorts.

The three cohorts of students agreed that the various instructor-assigned partners/teams were a good thing in the $1 \mathrm{~A}$ term, giving them an opportunity to work with a wide range of people in their class. They did, however, report that there were occasions where their assigned partners either didn't pull their weight, or completed the entire assignment by themselves, with one student commenting:

$1 A$ was a hodge podge of people trying to fit into a hierarchy... In GENE 121, certain weeks I didn't like my partner. One week my partner didn't know anything. But it helped meeting people, learning names. It helped a lot.

CEEA 17; Paper 035

University of Toronto; June 4-7, 2017 
There was also general agreement that instructorassigned teams were acceptable for projects or assignments with short timelines, but for multi-week projects, they would like to select their own teams. Some of the participants realized that the real world doesn't always provide the opportunity to select your own teams, and that life skills can be learned through working with people you don't necessarily like. The older students also spoke directly to the problems that can arise when working with your friends:

A: I worked with a friend in $1 B$ in an assigned group. I had the same experience [not feeling an obligation to do the work because you're friends]. You don't want to be mean, but we need to get this done. Friends take this less seriously. You work harder with people you don't know.

B: I avoid working with my closest friends on everything. If you do that, you limit yourself to a small social circle, which makes it harder to reach out to someone new. It can be hard to focus on the task as well, it feels like hanging out. You have to be open to the idea of working with new people.

The $2 \mathrm{~A}$ and $3 \mathrm{~A}$ students mentioned intentionally looking for new people to work with to meet as many people in their class as they possibly can. Students as early as $2 \mathrm{~A}$ were already looking forward to the fourth year capstone project and trying to identify people that they could work with. That the fourth year project was already on their minds in $2 \mathrm{~A}$ was a shock to the researchers, and should be investigated further. One $2 \mathrm{~A}$ student commented:

I intentionally choose different groups so there is no overlap between project groups. I want to work with lots of people to know my class for $4^{\text {th }}$ year capstone, but this is a big risk.

One question posed to all three cohorts was "What advice would you give a first year student about team formation?" This question generated some great responses:

A: Use 1A to get to know your classmates, you'll be spending 4+ years with them.

B: First year was to figure out who I like to work with, and who I work well with. These aren't necessarily the same people.

C: In first year, it's just going to be random anyways. You are going to get random groups and you just have to deal with it. Then as you go through the next two years, you find out the groups you want to be in. For me, I like to change my groups often, once I worked with one set of people, I want to work with different people because I go through everyone and find out who I work best with.

The $2 \mathrm{~A}$ and $3 \mathrm{~A}$ cohorts were asked if relationships which form during work terms persist into academic terms. The responses from both groups was that they did not, with students saying:

CEEA 17; Paper 035

University of Toronto; June 4-7, 2017
A: We went back to our original friend groups after co-op with my classmate, even though we worked well together

B: We worked well together, but we are in different social circles [in class]. I am not comfortable with his circle of friends.

C: Work term environments are very different from school environments.

The subject of groups forming around a common language came up with the $2 \mathrm{~A}$ cohort. Common language was seen as both a good starting point for forming a group, as well as having an isolating quality to students who do not speak the language:

A: Some people in residence spoke their own language within their group. It was hard to approach this group as an outsider. You know they speak English, but it creates a barrier.

B: When I speak my own language in front of others, it almost separates us in a different circle, everyone around you looks at you weird. It's not conducive to broaden the group's horizons

Like any other method of formation, it also doesn't guarantee success of the team:

Two people I speak Chinese with were looking for a partner, so I said I know someone else who speaks Chinese, and he's pretty cool. They got back to me and said they hate him, that he doesn't do anything, which was a surprise to me because I thought he was hard working. Maybe they just don't work well together, that the shared language isn't enough to get over the fact that they can't work well together.

The two female participants from the 3A cohort had an important discussion around women in their class, which is repeated in full here:

Female 1: I would like to comment on the whole male-female thing in our class. Right now, you're comfortable with everyone, but at the outset, in $1 \mathrm{~A}$ a lot of the females who came into Tron had the same experience as me, you are here to learn, you aren't supposed to know everything already [like the males were portraying], so personally, I felt more comfortable with females, just for first term. Our team was made up of 3 girls... It's seldom you find one female in an all male group, I don't know if that is just a coincidence.

Female 2: for my group, it was three guys and me. I made it clear that I wanted to do stuff: coding, and design of the robot. It ended up happening that whenever we got together, I got stuck with the documentation, with making presentations, the more secretarial work. Which I don't mind because I enjoy $i t$, but at the same time it's not cool that I don't get the more engineering side of it. I feel like that isn't just the 1A project, but also [on work term] 
Female 1: this isn't just for [mecha]tron[ics], this is more general. I feel like people aren't critical of your engineering abilities, so much as your social abilities, especially when working in groups. Ifeel like women will get criticized or praised for being able to hold a team together, being enthusiastic, things like that. But if you ask your employer, hey, how am I doing technically? They're like, oh, you're fine! But it's not very specific. You don't know how you can exceed expectations, all you know is you're doing fine.

\section{FURTHER WORK}

The discussion in the focus group sessions turned to the issue of students who transfer into the cohort from outside (from upper years of MTE, other engineering programs, or other faculties). It was mentioned in a number of focus group sessions that cliques formed fairly early in the program, which made integration of new people a challenge. This phenomenon would need to be studied further to see how widespread an issue it is, and to see what interventions could aid these students to integrate with their new cohorts more quickly, especially if they enter in upper years of the program.

A common thread in the focus group sessions was that students, even as early as second year, were already thinking about their fourth year capstone projects. This focus, so early in the program, was very surprising to the researchers. How healthy this is for the students is totally unknown. It is also unknown how pervasive this is in other programs, both at UWaterloo, and at other campuses.

Lastly, the issue of diversity on student academic teams begs for further study. The issues of foreign language speakers, and under-represented minority groups came up in the focus groups. Women are highly underrepresented in Mechatronics, and so investigation into the issues they face when forming academic teams, and what can be done to improve their situation moving forwards is badly needed.

\section{CONCLUSIONS}

The original hypothesis that students form their teams based on some combination of teammates from prior teams/partnerships was not wholly correct. In addition, the common wisdom, that student teams form out of friendships and proximity to their classmates (e.g. roommates) is also not correct. Students, even first year students, as in this study, are much more strategic with who they work with than they are given credit for.

While there is limited data at this stage, it appears that providing students with a significant early team experience, even if the stakes are low (such as with Tron days), leads to higher student satisfaction in choice of teammates later in the semester. This fits with Tuckman's model of team formation [9]: if the students get past the "Storming" phase in the low stakes activity, they enter at the "Performing" phase in the high stakes project.

One powerful takeaway from this study is the importance of building class community early in the students' first term on campus. The researchers were surprised at the lasting impact of first year orientation week on friendships and project teams, for example.

Lastly, while students will always complain when given assigned teams/partners, the students from this study appreciated the instructor-assigned partners/teams to help break the ice with their classmates. These students do, however, want the power to pick their own teammates "when it counts", especially outside of first year.

\section{REFERENCES}

[1] T. J. Scott and J. H. Cross, "Team Selection Methods for Student Programming Projects," in 8th Conference on Software Engineering Education, New Orleans, 1995.

[2] M. L. Connerley and F. A. Mael, "The Importance and Invasiveness of Student Team Selection Criteria," Journal of Management Education, vol. 25, no. 5, pp. 471-494, 2011.

[3] K. Deibel, "Team Formation Methods for Increasing Interaction During In-Class Group Work," in Innovation and Technology in Computer Science Education, Monte de Caparica, 2005.

[4] B. Oakley, R. M. Felder, R. Brent and I. Elhajj, "Turning student groups into effective teams," The Journal of Student Centered Learning, vol. 2, no. 1, pp. 9-34, 2004.

[5] A. Hurst, R. Al-Hammoud, A. Prier, M. Mostafapour, C. Rennick, C. Hulls, J. Grove, E. Li and S. Bedi, "Teamwork for Enginereing Students: Improving Skills Through Experiential Teaching Modules," in Canadian Engineering Education Association Conference, Toronto, 2017.

[6] C. Hulls, C. Rennick, M. Robinson, W. Melek and S. Bedi, "Integrative Activities for First-Year Engineering Students - Fuel Cell Cars as a Linking Project Between Chemistry, Mechatronics Concepts and Programming," in Canadian Engineering Education Association Conference, 2014, 2014.

[7] E. Li, C. Rennick, C. Hulls, M. CooperStachowsky, E. Boghaert, M. Robinson, W. Melek and S. Bedi, "Tron Days: Horizontal Integration and Authentic Learning," in Canadian Engineering Education Association Conference, Toronto, 2017. 
Proc. 2017 Canadian Engineering Education Association (CEEA17) Conf.

[8] C. Hulls, C. Rennick, S. Bedi, M. Robinson and W. Melek, "The Use of an Open-Ended Project to Improve the Student Experience in First Year Engineering," in Canadian Engineering Education Association Conference, Hamilton, 2015.
[9] B. W. Tuckman, "Developmental sequence in small groups," Psychological Bulletin, vol. 63, no. 6, pp. 384-399, 1965. 